\title{
Radio Frequency Sensing of Particulate Matter Accumulation on a Gasoline Particulate Filter
}

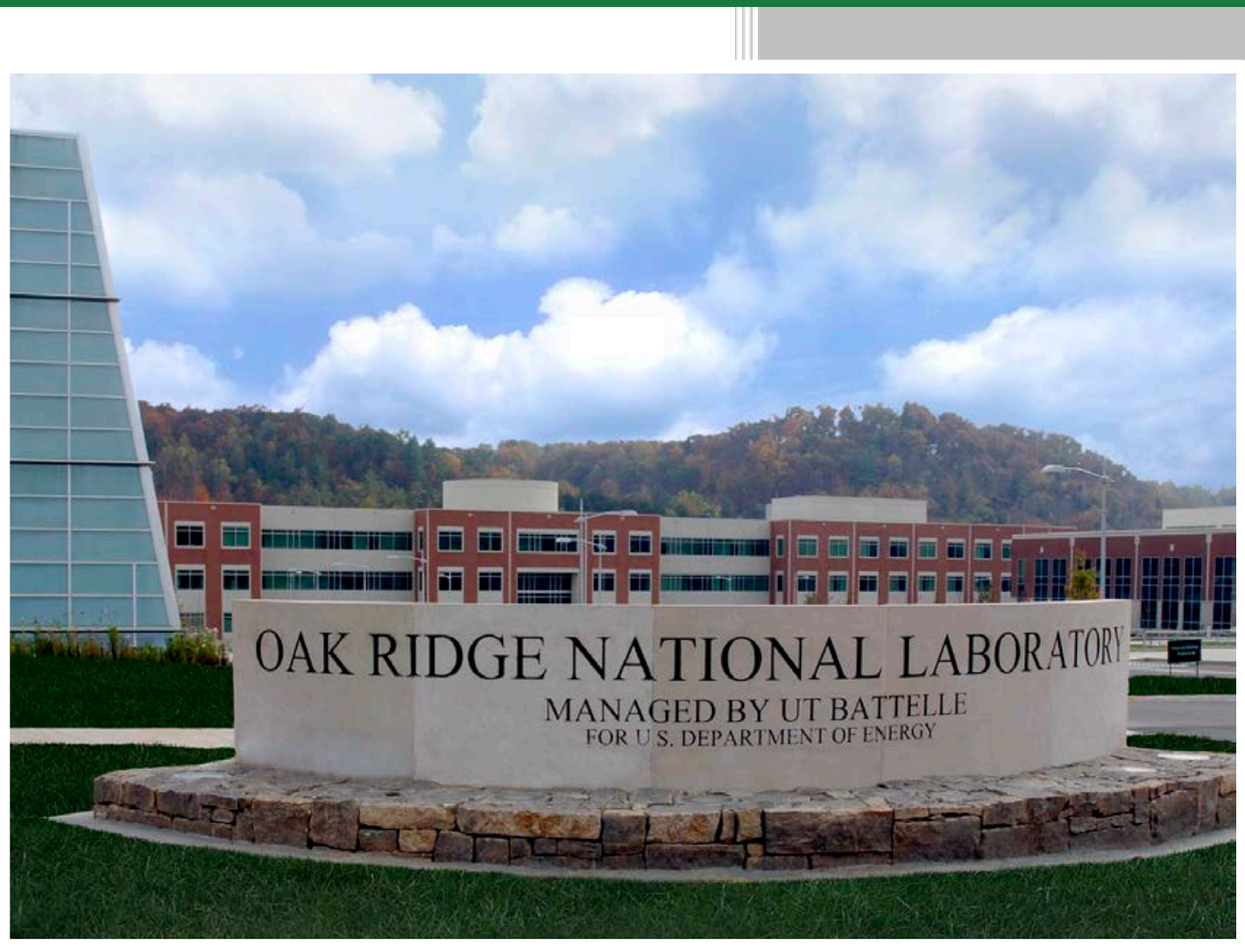

\section{CRADA FINAL REPORT \\ NFE-16-06037}

Approved for Public Release. Distribution is Unlimited.
Jim Parks

Vitaly Prikhodko

Alex Sappok

Paul Ragaller

Leslie Bromberg

October 30, 2016 


\section{DOCUMENT AVAILABILITY}

Reports produced after January 1, 1996, are generally available free via US Department of Energy (DOE) SciTech Connect.

Website http://www.osti.gov/scitech/

Reports produced before January 1, 1996, may be purchased by members of the public from the following source:

National Technical Information Service

5285 Port Royal Road

Springfield, VA 22161

Telephone 703-605-6000 (1-800-553-6847)

TDD 703-487-4639

Fax 703-605-6900

E-mail info@ntis.gov

Website http://www.ntis.gov/help/ordermethods.aspx

Reports are available to DOE employees, DOE contractors, Energy Technology Data Exchange representatives, and International Nuclear Information System representatives from the following source:

Office of Scientific and Technical Information

PO Box 62

Oak Ridge, TN 37831

Telephone 865-576-8401

Fax 865-576-5728

E-mail reports@osti.gov

Website http://www.osti.gov/contact.html

This report was prepared as an account of work sponsored by an agency of the United States Government. Neither the United States Government nor any agency thereof, nor any of their employees, makes any warranty, express or implied, or assumes any legal liability or responsibility for the accuracy, completeness, or usefulness of any information, apparatus, product, or process disclosed, or represents that its use would not infringe privately owned rights. Reference herein to any specific commercial product, process, or service by trade name, trademark, manufacturer, or otherwise, does not necessarily constitute or imply its endorsement, recommendation, or favoring by the United States Government or any agency thereof. The views and opinions of authors expressed herein do not necessarily state or reflect those of the United States Government or any agency thereof. 
ORNL/TM-2016/679

CRADA/NFE-16-06037

Energy and Transportation Science Division

\title{
Radio Frequency Sensing of Particulate Matter Accumulation on a Gasoline Particulate Filter
}

Jim Parks and Vitaly Prikhodko (Oak Ridge National Laboratory) Alex Sappok, Paul Ragaller, and Leslie Bromberg (Filter Sensing Technologies)

Date Published:

October 30, 2016

\author{
Prepared by \\ OAK RIDGE NATIONAL LABORATORY \\ Oak Ridge, Tennessee 37831-6283 \\ managed by \\ UT-BATTELLE, LLC \\ for the \\ US DEPARTMENT OF ENERGY \\ under contract DE-AC05-00OR22725
}

Approved for Public Release 


\title{
Radio Frequency Sensing of Particulate Matter Accumulation on a Gasoline Particulate Filter
}

\begin{abstract}
Filter Sensing Technology's radio frequency (RF) sensor for particulate filter on-board diagnostics (OBD) was studied on a lean gasoline engine at the National Transportation Research Center (NTRC) at Oak Ridge National Laboratory (ORNL). The response of the RF sensor to particulate matter (PM) or "soot" accumulation on the gasoline particulate filter (GPF) installed in the engine exhaust was evaluated. In addition, end plugs of the GPF were purposely removed, and subsequent changes to the RF sensor measured soot loading on the GPF were characterized. Results from the study showed that the RF sensor can accurately measure soot accumulation on a GPF; furthermore, the predicted decreased soot accumulation due to plug removal was detected by the RF sensor. Overall, the studies were short and preliminary in nature; however, clearly, the RF sensor demonstrated the capability of measuring GPF soot loading at a level suitable for use in lean gasoline engine emission control OBD and control.
\end{abstract}

\section{Statement of Objectives}

The objectives of the study were:

(1) determine if the Filter Sensing Technologies (FST) RF sensor can detect particulate matter ("soot") accumulation on a gasoline particulate filter (GPF), and

(2) characterize changes in soot loading on the GPF as measured by the RF sensor for failure modes simulated by the removal of end plugs in the GPF substrate.

\section{Benefits to the Funding DOE Office's Mission}

This CRADA (Cooperative Research And Development Agreement) project was funded by the Vehicle Technologies Office of the U.S. Department of Energy (DOE). A core mission of DOE is energy security which is achieved through the reduction of petroleum usage by more fuel-efficient vehicle technologies. As new fuel-efficient vehicles are developed and introduced to the marketplace, they must meet U.S. Environmental Protection Agency (EPA) requirements for tailpipe emissions to insure minimal impact to air quality and human health.

The subjects of this study, FST's RF sensor and GPFs, are important elements that enable vehicles to meet EPA's emission regulations for PM emissions. Specifically, lean gasoline engines can enable vehicles to achieve 10-15\% better fuel economy for vehicles with stoichiometric gasoline engine technology; however, PM emission from lean gasoline engines are significantly higher than from stoichiometric engines. Therefore, GPF emission control of PM will likely be required for lean gasoline engine vehicles to meet EPA regulations and be commercialized. Of specific interest is compliance to EPA Tier 3 emissions for light-duty vehicles which requires less than $3 \mathrm{mg} / \mathrm{mile}$ PM emissions. Note that emission control devices such as GPFs must include OBD to insure proper function of the device during real-world operation.

In summary, this CRADA focuses on RF sensor and GPF technologies that enable the introduction of fuel-efficient lean gasoline engine vehicles by achieving low PM emissions that meet EPA regulations. The introduction of fuel-efficient lean gasoline engine vehicles can reduce petroleum use, decrease Greenhouse Gas emissions, and increase energy security. 


\section{Technical Discussion of Work Performed by All Parties}

Experiments were conducted on ORNL's lean gasoline engine platform which consists of a BMW 2.0liter, 4-cylinder naturally-aspirated lean gasoline engine with full pass control via a National Instruments Powertrain controller. The engine is unique in that the combustion system was designed to operate both with excess air (lean), and with fuel-air equivalency (stoichiometric). The engine is attached to an engine dynamometer for speed and load control. The engine operates in three different OEM (original equipment manufacturer) combustion modes: lean stratified, lean homogeneous, and stoichiometric (homogeneous). The lean stratified mode offers the leanest operation and greatest fuel efficiency, but at higher loads and speeds, the engine is not capable of lean stratified combustion and lean homogenous or stoichiometric modes must be used. PM emissions are highest for the lean stratified mode; also, rich operation for active regeneration of emission controls systems (e.g. lean NOx trap) generates significant PM. A summary of PM emissions can be found in the literature from previous studies of GPF control of PM on this engine. ${ }^{\mathrm{i}}$

A GPF manufactured by Corning was installed in the engine exhaust system (Figure 1). The GPF was a 200 cpsi wall-flow cordierite substrate with 5.2" diameter by 5" long dimensions. Wall thickness was 8 mil. The FST RF sensor was applied to the GPF with antenna at the inlet and outlet cones of the GPF housing, and the RF signal was processed and logged with FST's controller and computer interface. An AVL Micro Soot Sensor (MSS) was used to characterize PM mass emissions from the engine. An MKS Fourier Transform Infrared spectrometer and gas transmission cell were used for gaseous emissions measurement.

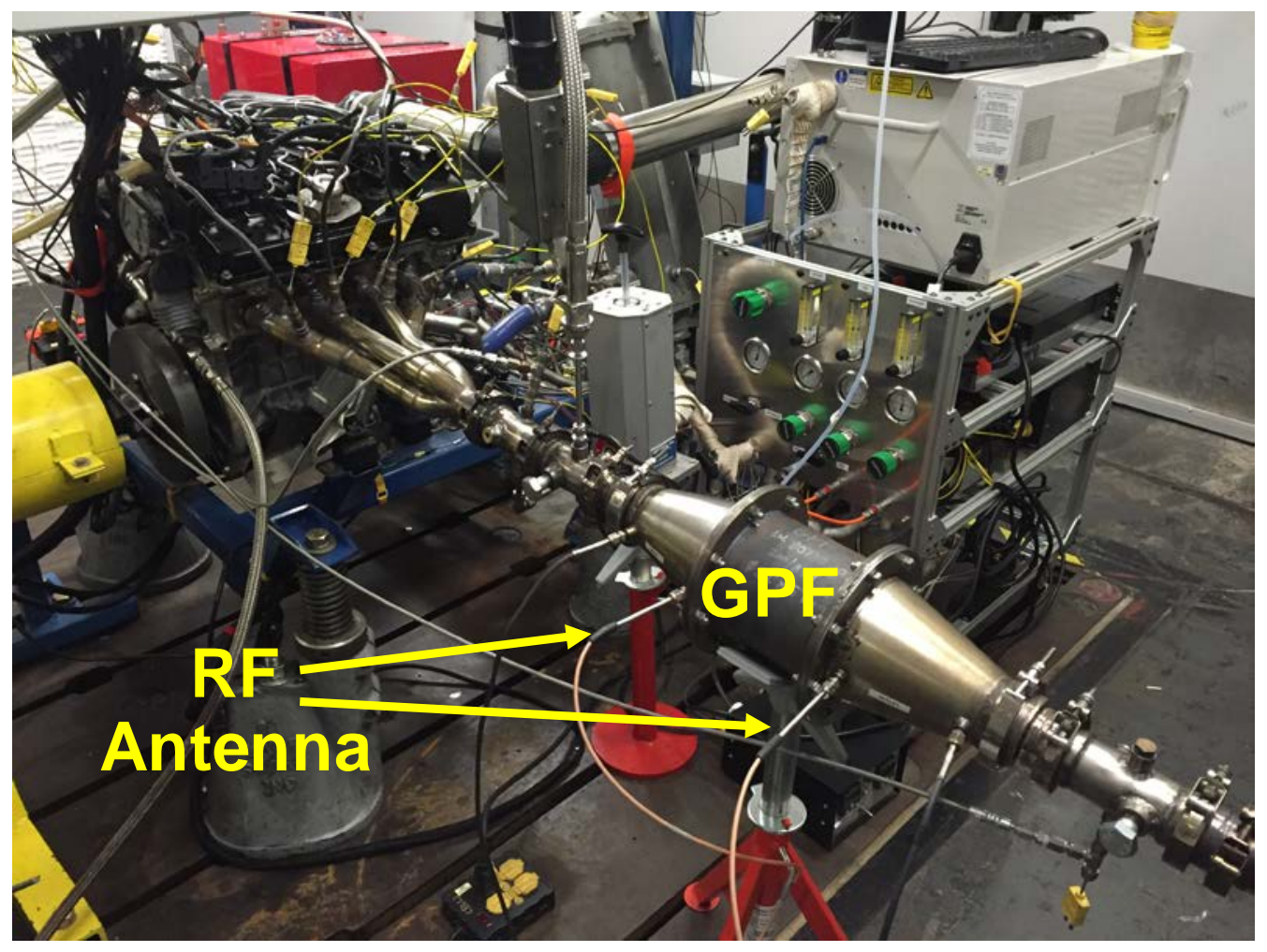

Figure 1. Photograph of the engine and GPF setup. The RF sensor antenna are shown at the inlet and outlet of the GPF. 
An example of engine out PM emissions at $2000 \mathrm{rpm}$ and $50 \mathrm{ft}-\mathrm{lb}$ as a function of combustion mode is shown in Figure 2. Lean stratified combustion generates on average $14.3 \mathrm{mg} / \mathrm{m}^{3}$ of PM while stoichiometric combustion generates an average of $3.3 \mathrm{mg} / \mathrm{m}^{3} \mathrm{PM}$. Note that these measurements were obtained under cold engine conditions. By integrating data as shown in Fig. 2, the PM or "soot" loading of the GPF can be determined. For example, cycling between lean stratified and stoichiometric operation as shown in Fig. 2 for 3 hours resulted in $0.7 \mathrm{~g} / \mathrm{L}$ soot loading on the GPF. Here the mass loading is normalized to volume based on the displacement volume of the GPF substrate.

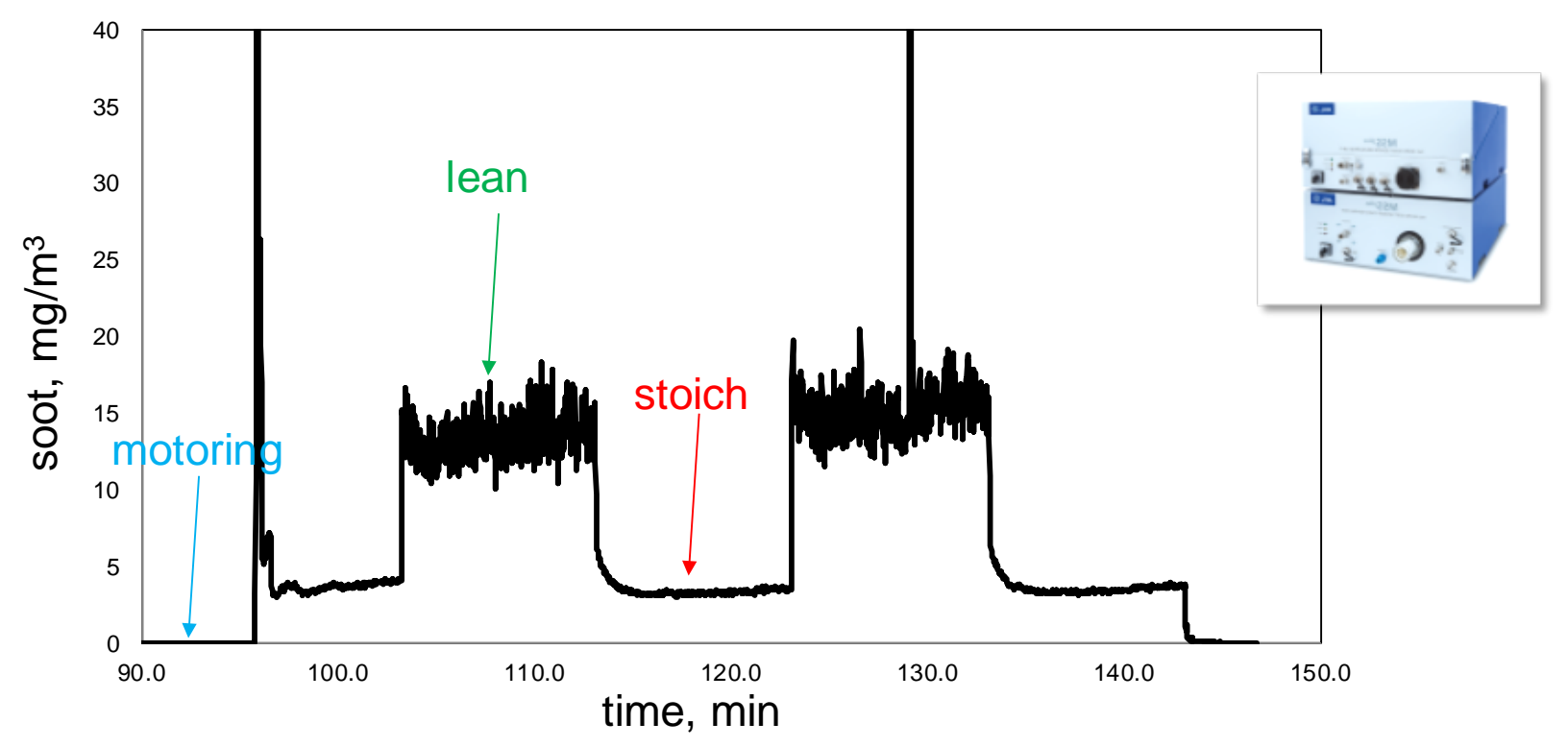

Figure 2. PM emissions measured by the AVL Micro Soot Sensor (shown in inset) as a function of time during lean stratified ("lean”) and stoichiometric ("stoich") modes of combustion at $2000 \mathrm{rpm}$ and $50 \mathrm{ft}-$ lb. For reference, "motoring” indicates the engine is spinning on the dynamometer with no combustion occurring.

During initial studies, the FST RF sensor was able to detect soot accumulation on the GPF. Considering that lean gasoline engines emit considerably less PM than diesel engines (where the FST RF sensor has previously demonstrated soot loading measurement capability), the fact that the FST RF sensor could measure the lower soot accumulation rates from a lean gasoline engine is significant. The project focused on determining whether or not the FST RF sensor could detect GPF failure and thereby serve as an OBD sensor. To conduct the study, the GPF was loaded with a repeated sequence of engine operation consisting of 3 minutes of stoichiometric operation followed by 10-20 sec of lean stratified operation at $2000 \mathrm{rpm}$ and $50 \mathrm{ft}-\mathrm{lb}$. The engine out and GPF outlet (or "GPF out") soot concentration in the exhaust is shown in Figure 3 for this sequence. Note that the AVL MSS instrument can only sample from one location at a time; so, the time frame shown for each position does not represent the exact same time but is representative of the repeatable data observed. The sharp spikes in soot at the engine out position correspond with the lean stratified mode which has a much higher rate of soot emissions as compared with stoichiometric operation. The lack of emissions in the GPF out position shows that the GPF is highly effective at filtering the PM. Note that during the course of the study, occasionally the GPF was cleaned by operating the engine at $3000 \mathrm{rpm}$ and $65 \mathrm{ft}-\mathrm{lb}$ which produced sufficient heat to thermally oxidize any trapped soot on the GPF. 

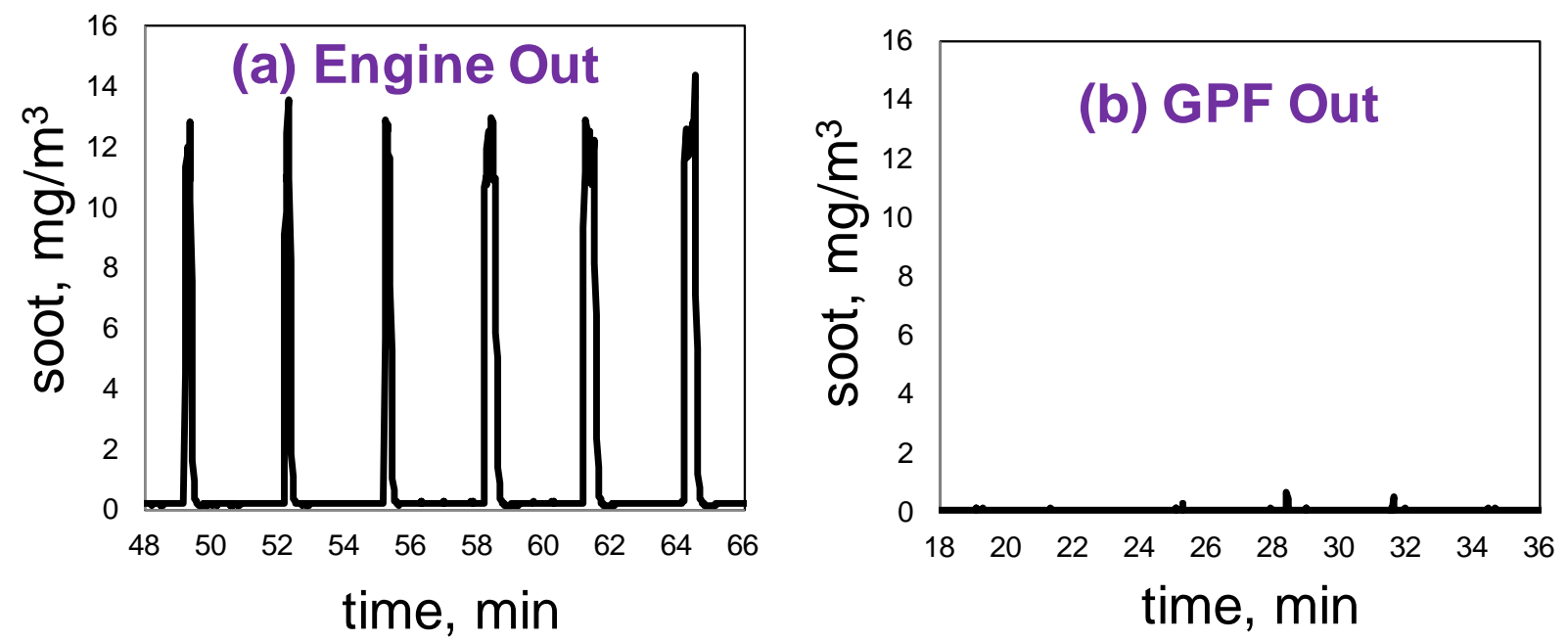

Figure 3. PM emissions measured at the engine out (a) and GPF out (b) positions in the exhaust system for the repeated sequence of 3 minutes of stoichiometric operation followed by 10-20 sec of lean operation.

Using the sequence shown in Fig. 3, the response of the RF sensor to simulated GPF failure was studied. Simulated failure was created by purposely removing a number of the end plugs on the downstream side of the GPF substrate. Hence, after plug removal, soot flowing down that channel of the GPF was not filtered and instead exited the GPF substrate untreated on the downstream side. First, a section of end plugs representing a cell area of 8 by 8 cells were removed. Figure 4 shows a photograph of the removed end plugs and the associated change in the PM emissions measured at the GPF outlet. As observed in the data, spikes of PM emissions associated with the repeated lean stratified operation become evident from the PM escaping from the 8 by 8 cell area with the end plugs removed.

\section{$8 \times 8$ removed}

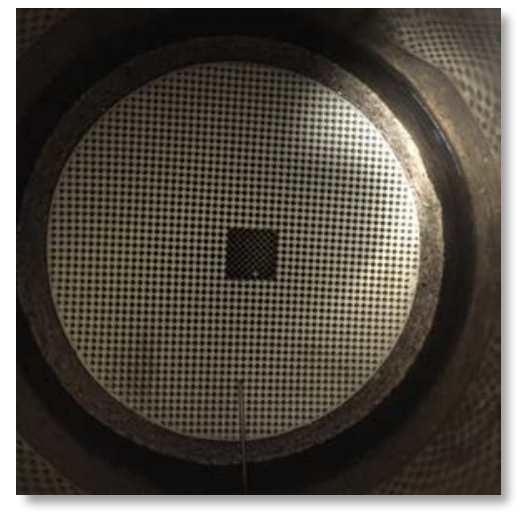

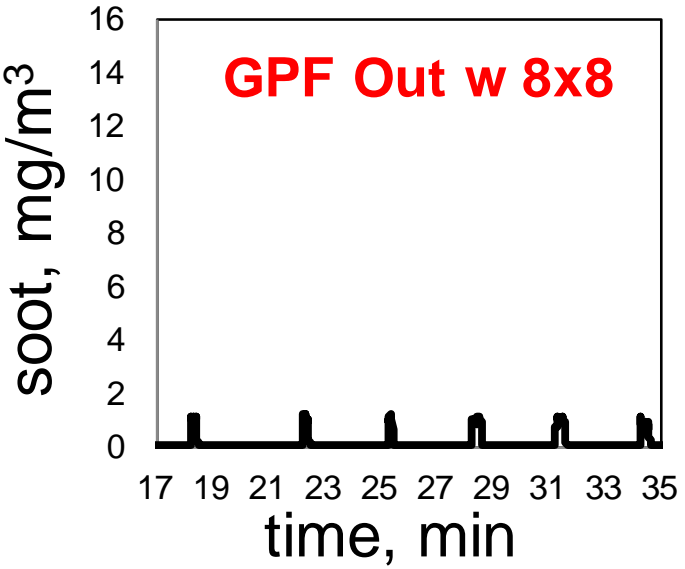

Figure 4. Photograph of the downstream side of the GPF substrate with an 8 by 8 cell area of end plugs removed (left) and the corresponding PM emissions measured at the GPF out position (right). 
An additional failure point was created in the same fashion but with more end plugs removed. In the second case, end plugs were removed from a 16 by 17 cell area on the downstream side of the GPF substrate. The corresponding photograph and PM emissions measured at the GPF outlet are shown in Figure 5. As expected, larger PM emission spikes were observed at the GPF outlet associated with the larger number of end plugs removed.

\section{$16 \times 17$ removed}
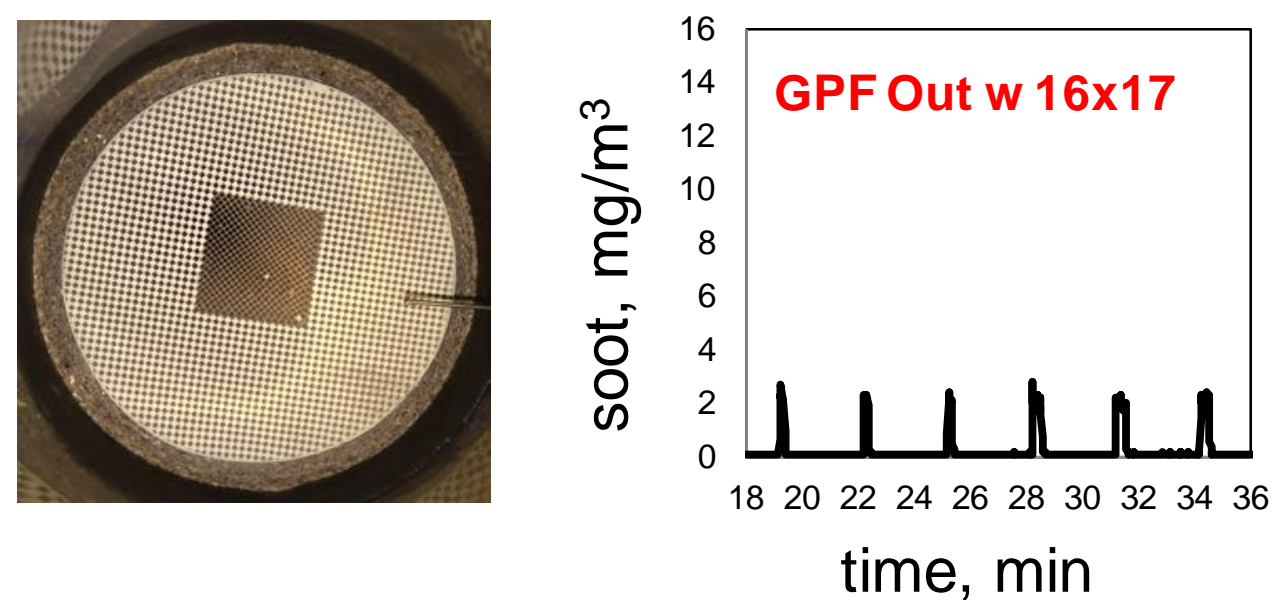

Figure 5. Photograph of the downstream side of the GPF substrate with a 16 by 17 cell area of end plugs removed (left) and the corresponding PM emissions measured at the GPF out position (right).

Performance of the GPF and FST RF sensor were measured for the cases with the GPF fully intact and with the simulated failure states associated with removal end plugs for 8 by 8 and $16 \times 17$ cell areas. The AVL MSS data was utilized to determine the soot load on the GPF for all three of these states as a function of time during GPF loading. The data is shown in Figure 6. As expected, the soot loading increases at the highest rate for the intact GPF case since essentially all of the soot emitted is being trapped by the GPF. In contrast, the cases where simulated failure was induced show slower rise rates in the amount of soot trapped by the GPF since some of the soot is being emitted downstream of the GPF through the area with the end plugs removed. As expected the slowest rise rate in soot load is associated with the case where the highest number of end plugs was removed (the 16 by 17 cell area case).

The data from the FST RF sensor was analyzed for the same cases and was able to detect the differences between all three cases; the RF sensor data is shown in Figure 7. Similar to the data obtained from the AVL MSS data (Fig. 6), the RF sensor data shows the highest soot loading rate for the intact GPF, and the slowest rise rate in the soot loading is observed for the 16 by 17 cell area end plug removal case which has the highest amount of soot slipping through the removed end plugs on the downstream side of the GPF. It is interesting to note that the 8 by 8 cell area end plug remove case only slightly affects the soot loading. The difference between the intact and 8 by 8 cases is significant and well resolved by the RF sensor. Since more than four times the area of end plugs is removed by the 16 by 17 case in comparison to the 8 by 8 case, it is logical to expect that the soot loading impact is much more severe for the 16 by 17 case (as observed). It is possible that the effect as a function of area of end plugs removed is non-linear since more exhaust flow may flow through the channels with the end plugs removed. Nonetheless, the FST RF sensor clearly shows the ability to detect failures in the GPF substrate for lean gasoline engine applications. 


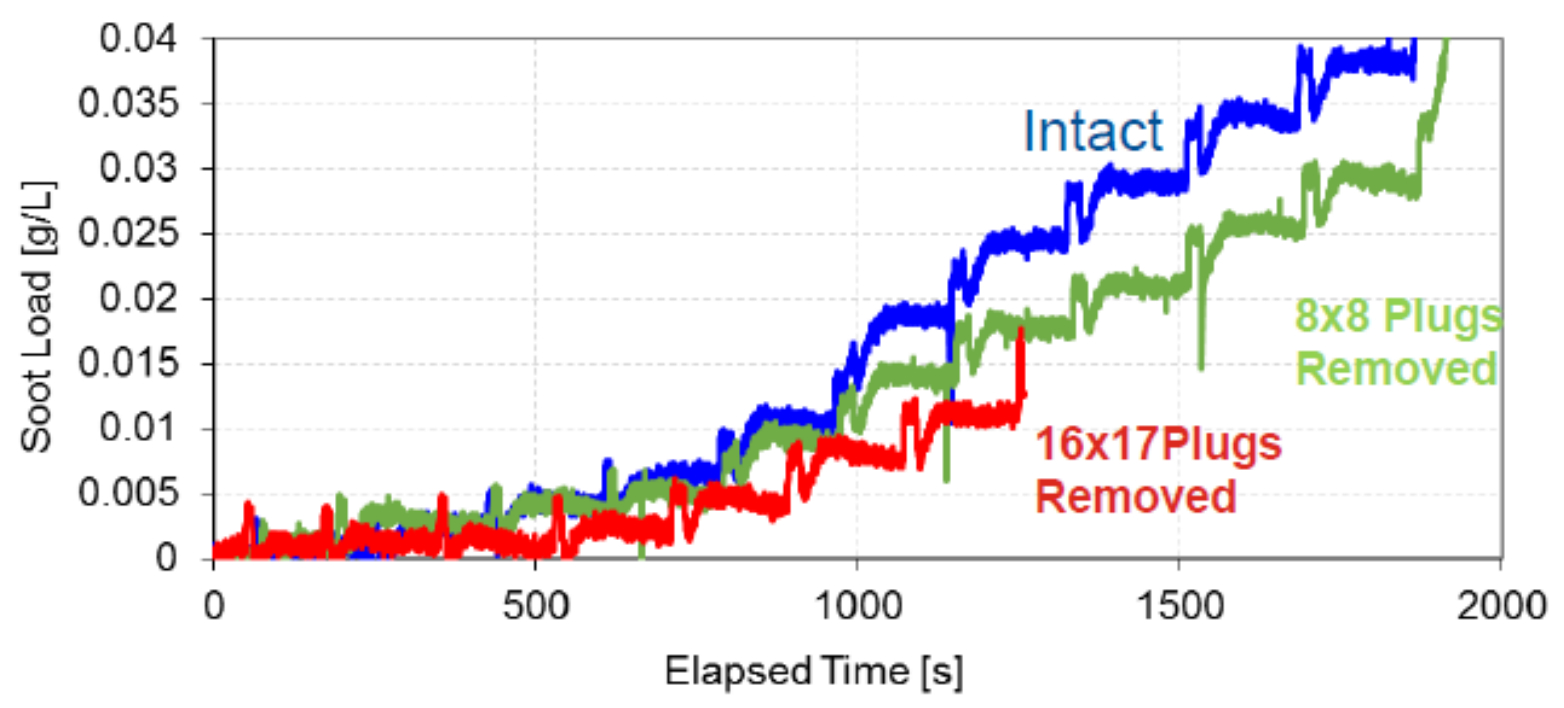

Figure 6. AVL MSS data showing soot load as a function of time for the GPF in the states of intact, with 8 by 8 cell area plugs removed, and with 16 by 17 cell area plugs removed.

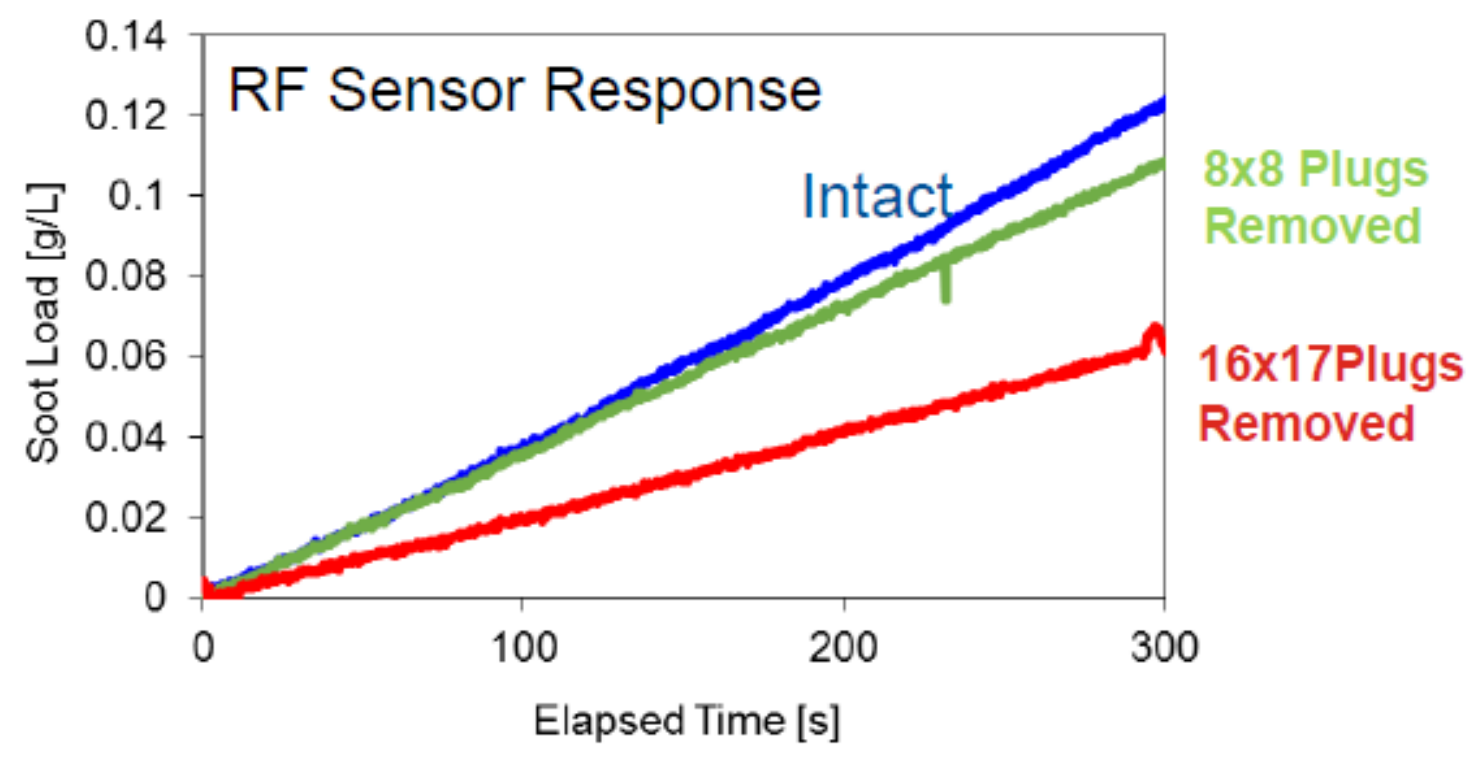

Figure 7. FST RF sensor data showing soot load as a function of time for the GPF in the states of intact, with 8 by 8 cell area plugs removed, and with 16 by 17 cell area plugs removed.

\section{Subject Inventions (As defined in the CRADA)}

No new inventions resulted from this CRADA. The CRADA focused on the study of FST's existing RF sensor technology for new applications.

\section{Commercialization Possibilities}

FST has done extensive development of their RF sensor for diesel applications (as applied to Diesel Particulate Filters). The diesel development includes field studies of the RF sensor on sanitation trucks in 
New York City. The new commercial opportunity relevant to this CRADA study is the RF sensor as applied to gasoline applications (with GPFs). Considering that the U.S. light-duty market is dominated by gasoline engine vehicles, there is a large commercial opportunity for RF sensors for gasoline vehicles. During the course of this project, FST was acquired by CTS, a $<\$ 500 \mathrm{M}$ corporation already actively supplying sensor technology to the transportation market; thus, there is continued interest in commercialization of RF sensors.

\section{Plans for Future Collaboration}

ORNL is continuing research of emissions control technologies for lean gasoline engines through DOE sponsored projects. The ORNL and FST collaboration has been very successful. Thus, we anticipate future collaboration opportunities especially for RF sensing for gasoline applications pending funding. Results from this CRADA have been presented at the Society of Automotive Engineers (SAE) On-Board Diagnostics Symposium on September 13-15, 2016 in Indianapolis, IN. An SAE technical paper including the results is being drafted for future release.

\section{Conclusions}

FST's RF sensor demonstrated the ability to detect soot accumulation on GPF technology installed in the exhaust of a lean gasoline engine. In addition, the detection sensitivity of the RF sensor was sufficient to detect changes in soot accumulation induced by simulated GPF failure where end plugs were removed from the GPF substrate. Thus, the RF sensor demonstrated utility for measure the status of the GPF soot loading and providing information relevant to OBD.

\section{Acronyms}

CRADA = Cooperative Research And Development Agreement

DOE $=$ (United States) Department of Energy

EPA $=($ United States) Environmental Protection Agency

FST $=$ Filter Sensing Technologies

GPF $=$ Gasoline Particulate Filter

NTRC $=$ National Transportation Research Center

OBD $=$ On-Board Diagnostics

ORNL = Oak Ridge National Laboratory

$\mathrm{PM}=$ Particulate Matter (commonly known as “soot”)

$\mathrm{RF}=$ Radio Frequency

\section{References}

i James E. Parks, John Storey, Vitaly Prikhodko, Melanie Debusk, Sam Lewis, "Filter-based control of particulate matter from a lean gasoline direct injection engine”, SAE Technical Paper Series 2016-01-0937 (2016). 